\title{
REFUGIADOS E DESLOCADOS AMBIENTAIS ${ }^{1}$
}

\author{
Tupinambá Pinto de Azevedo
}

\begin{abstract}
Resumo: tTrago aos senhores algumas ideias que tenho desenvolvido sobre temas que, por sua dramaticidade, preocupam a todos nós. Introdutoriamente, breve notícia da expansão, cumulação e fortalecimento ${ }^{3}$ dos direitos humanos, cada vez mais internacionalizados. É possível falar-se, separadamente, dos Direitos Humanos, o Direito Humanitário, e de um de seus pontos nevrálgicos, o Direito dos Refugiados. Mas, logo adiante, com base em Cançado Trindade, ${ }^{4}$ defendemos aproximações ou convergências entre tais vertentes, sob o título de Direito Internacional dos Direitos Humanos. Deparamo-nos, a seguir, com as mudanças climáticas, a biodiversidade e o uso sustentável de energia. Nada mais atual. Aquilo que se desenhava como possivelmente assustador, no século passado, agora está no centro de nossos estudos, traz manchetes na mídia, e ninguém pode ficar alheio a algo que afeta, inclusive, as próximas gerações. Os desastres, naturais ou provocados pelo homem, não
\end{abstract}

1 Desenvolvimento de texto a partir de palestra apresentado, na XVI Semana Acadêmica do Direito da Faculdade de Direito da ULBRA, Torres-RS, em Homenagem ao Prof. Des. MOACIR ADIERS, na noite de 21 de junho de 2013. Magistrado de escol, ADIERS é professor de Direito Privado, sendo notável o domínio que possui acerca das obras de HANS KELSEN e PONTES DE MIRANDA.

2 Docente convidado do Programa de Pós-Graduação em Direito (Faculdade de Direito - UFRGS). Desembargador estadual inativo. E-mail: tupinambah@terra.com.br

3 “A fantasia nefasta das chamadas gerações de direitos, histórica e juridicamente infundada, na medida em que alimentou uma visão fragmentada ou atomizada dos direitos humanos, já se encontra devidamente desmistificada. $\mathrm{O}$ fenômeno que hoje testemunhamos não é o de uma sucessão, mas antes de uma expansão, cumulação e fortalecimento dos direitos humanos consagrados consoante uma visão necessariamente integrada de todos os direitos humanos." CANÇADO TRINDADE, Antônio Augusto. Direitos humanos e Meio-Ambiente: Paralelo dos Sistemas de Proteção Internacional. Porto Alegre: S. A. Fabris Ed., 1993. p. 191-193.

4 Em outra obra do autor. ver notas de pé de página 7, 8, 9 - infra. 
são apenas prováveis, mas certamente danosos e capazes de colocar em risco o futuro do planeta. Depois, a particular atenção quanto aos refugiados. Mudando de assunto, algo sobre o ambiente, que deve ser ecologicamente equilibrado. Então, cruzaremos o direito dos refugiados e o direito ambiental, e nos defrontaremos com a iminência catastrófica das mudanças climáticas.

Palavras-chave: Direito dos Refugiados. Nacionalismo. Mudanças Climáticas. Projeto de Convenção Internacional sobre Deslocados Ambientais.

\section{INTRODUÇÃO}

O ponto de partida da internacionalização dos direitos humanos é a Declaração Universal, de 1948, a que se seguiram os Pactos Internacionais de Direitos Civis e Políticos, e o de Direitos Econômicos, Sociais e Culturais, que estão vigorando desde 1976. Desde então, efetiva-se o sistema mundial de direitos humanos, com seus órgãos especiais e sua arquitetura jurídica baseada em tratados e convenções. Mas a primeira formação dos direitos humanos é bem anterior, na transição do feudalismo para o Estado Liberal. Começa com a independência dos Estados Unidos e, em sua constituição, um Bill of Rights, exigência das colônias lá existentes. Cada uma tinha sua própria Carta, vinda da Inglaterra, e que previa garantias. A Constituição norte-americana dependia de aprovação em referendo de Estados, e então Thomas Jefferson redige uma Carta de Direitos, e a finalidade não é proteger o povo, e sim os proprietários. Por isso se diz que aí aparece, nessa primeira geração de direitos humanos, a garantia de direitos individuais. Vitória da burguesia sobre os nobres. Que também ocorreria na França revolucionária, pouco depois da independência americana. E o principal colaborador da Declaração dos Direitos do Homem e do Cidadão era o mesmo Thomas Jefferson, à época, morando na França. Quais eram esses direitos? De liberdade, de livre iniciativa econômica, de livre expressão, de liberdade política. ${ }^{5}$

5 Em realidade, o primeiro Bill of Rights vem da Inglaterra, quando novos soberanos, Guilherme II e Maria II, aceitaram integralmente uma Declaração de Direitos, aprovada pelo Parlamento, terminando com a monarquia absoluta. Em verdade, esse Bill representou a separação de poderes, e foi promulgado "exatamente um século antes da Revolução Francesa". COMPARATO, Fábio Konder. A Afirmação Histórica dos Direitos Humanos. IV ed. São Paulo: Ed. Saraiva, 2005, p. 90. A descrição feita aqui, das gerações de direito, tem base na obra de Comparato. V. CAPPELLETTI, Mauro. Proceso, ideologias, sociedad. Buenos Aires: Ed. Jurídicas Europa-America, 1974. Terceira seção: Justiça e Pobreza (p. 131-153), Pobreza e Justiça (p. 154-182), Defensor del Pobre (p. 203-214) e La asistencia judicial a los no habientes; un paso demasiado pequeño y demasiado lento (p. 215- 224). 
A $2^{\mathrm{a}}$ onda, na qual está presente a expansão, cumulação e fortalecimento de direitos, vem com o surgimento da classe operária. Em voga, ideias socialistas. É a emergência dos Direitos Coletivos: direitos sociais e econômicos. Se de início o indivíduo se defendia da intromissão do Estado, agora, o indivíduo e as comunidades exigem ação positiva do Estado. $\mathrm{Ou}$ seja, o Estado deve proteger o indivíduo. Então, direito do trabalho, à organização sindical, à previdência (amparando idosos, acidentados, etc.); direito à educação gratuita, estabilidade no emprego.

Nova expansão, falando em Direitos de Solidariedade, matéria do pós II guerra: direitos individuais e sociais, com abrangência universal. Essa onda veio vacinada pela luta contra o totalitarismo, e introduziu direitos e interesses difusos, com ênfase na internacionalização: direito à paz, à autodeterminação dos povos, à informação, à privacidade, do consumidor, do meio ambiente. Mais uma vez, convoca-se o Estado, agora com atuação positiva, fortalecendo instituições como o Ministério Público, a Defensoria Pública, ${ }^{6}$ as ONGS, que se dizem não-governamentais mas, a exemplo de muitos sindicatos, vivem à sombra do Estado, salvo honrosas exceções.
Todos esses direitos, independentemente de gerações, são complementares e integrados. Norberto Bobbio ${ }^{7}$ falava em uma quarta expansão, que denominava a dos biodireitos, pertinentes à ética $\mathrm{e}$ à biogenética. $\mathrm{O}$ ser humano, dizia, enquanto integrado em espécie biológica, teria biodireitos, sobressaindo o controle da engenharia genética. Falamos, já, em visão homocêntrica-intergeracional do meio ambiente, ecocêntrica (proteção dos próprios ecossistemas e seus componentes) e, por fim, com normas trazidas do neoconstitucionalismo, a ética do ecologismo constitucional/ convencional.

Situemos, indiferentemente, em quaisquer fases dos direitos humanos, o crescimento da internacionalização. $\mathrm{O}$ aumento das desigualdades sociais nos países ditos periféricos, pedia um novo direito internacional, colocando em xeque as questões da democracia interna e da soberania nacional. A chamada positivação internacional dos Direitos Humanos, com normas sancionatórias, colocam os Estados no banco dos réus, e isso é promissor, mas de difícil implementação. Além de que justamente o aumento das desigualdades sociais levam a maior rigidez na área penal.

6 ver CAPPELLETTI, Mauro. Proceso, ideologias, sociedad. Buenos Aires: Ed. Jurídicas Europa-America, 1974. Terceira seção: Justiça e Pobreza (p. 131-153), Pobreza e Justiça (p. 154-182), Defensor del Pobre (p. 203-214) e La asistencia judicial a los no habientes; un paso demasiado pequeño y demasiado lento (p. 215-224).

7 ver BOBBIO, Norberto. A Era dos Direitos. Rio de Janeiro: Ed. Campus, 1992. 


\section{DIREITO DOS REFUGIADOS}

1. Falamos de Direitos Humanos. Acrescentemos, agora, o chamado Direito Internacional Humanitário, parte do direito internacional público relacionada com a guerra (direitos de Genebra e Haia), onde se incluem questões de refugiados e deslocados internos, de tratamento de prisioneiros de guerra $\mathrm{e}$ proteção de civis em tempos bélicos. $\mathrm{O}$ Direito Humanitário encontrou, no Tribunal Penal Internacional, importante reforço para a repressão ao genocídio, crimes contra a humanidade e crimes propriamente de guerra, pois é Corte basicamente voltada para a proteção e reparação das vítimas.

2. E o Direito dos Refugiados? A doutrina clássica revelava uma visão compartimentalizada de três grandes vertentes da proteção internacional da pessoa humana (Direitos Humanos DH, Direito Internacional do Direito Humanitário-DIDH e Direito dos Refugiados - DR), devido à ênfase nas origens históricas distintas. O Direito Humanitário (DIDH) serviria para pro- teger as vítimas de conflito armado, e o dos Refugiados (DR), para restabelecer direitos humanos mínimos dos indivíduos ao saírem do seu país de origem.

Atualmente, não caberia mais falar em vertentes ou ramos da proteção internacional da pessoa humana, pois se manifestam convergências em relação às três vertentes. " "No plano substantivo ou normativo, a interação é manifesta."

Se a criação de tribunais constitucionais levou à confluência entre positivismo e jusnaturalismo, é possível ver, no Direito Internacional dos Direitos Humanos (expressão de Cançado Trindade) ${ }_{1}^{10}$ uma positivação de direitos e o estabelecimento de uma antropologia jurídica mínima, com a superação de antinomias. Levando-nos a uma nova pirâmide jurídica, em que, acima das Constituições dos Estados soberanos, há que considerar Tratados e Convenções Internacionais de Direitos Humanos. Daí falar-se em Controle de Convencionalidade. ${ }^{.1}$

O Direito dos Refugiados começa a tomar forma em 1950, com o Estatuto do Alto-Comissariado das Nações Unidas para Refugiados (UNHCR); depois,

8 CANÇADO TRINDADE, Antônio Augusto. Tratado de Direito Internacional dos Direitos Humanos, v. I, 2 ed. Porto Alegre: Sérgio Antonio Fabris Ed., 2003. v. cap. VIII: As três vertentes da Proteção Internacional da Pessoa Humana: aproximações ou convergências entre os Direitos Humanos, o Direito Humanitário e o Direito dos Refugiados, p. 339-503. 9 Id., ibid., p. 341.

10 Como ficou claro na obra supra (Tratado de Direito Internacional dos Direitos Humanos. 3 v.).

11 Ver MAZZUOLI, Valerio de Oliveira. O controle jurisdicional da convencionalidade das leis. São Paulo: Revista dos Tribunais, 2009. 
a Assembleia Geral das Nações Unidas, em 1951, publica a Convenção Relativa ao Estatuto dos Refugiados, ${ }^{12} \mathrm{com}$ plementada com o Protocolo de 1967, Sobre o Estatuto dos Refugiados. O conceito inicial de refugiado - alguém com receio fundamentado de perseguição, por razões de "raça, religião, nacionalidade, participação em grupo social ou convicção política, encontrando-se fora do país de que é nacional e está impossibilitado ou, em virtude desse fundado medo, não deseja se entregar à proteção desse país" -, será alargado na Convenção da OUA, ${ }^{13}$ tratando de refugiados na África. Consta do art. $1^{\circ}$, inciso 2, a ampliação do termo refugiado, incluindo, agora, a todos aqueles que, diante de agressão exterior, uma ocupação ou dominação externa, ou, ainda, de fatos capazes de perturbar gravemente a ordem pública, parcial ou totalmente "de seu país de origem ou do país de sua nacionalidade, está obrigada a abandonar sua residência habitual para buscar refúgio em outro lugar fora do seu país de origem ou do país de sua nacionalidade." ${ }^{14}$
Finalmente, a Declaração de Cartagena, da OEA, ${ }^{15}$ inclui entre os refugiados "as pessoas deslocadas dentro de seu próprio país". ${ }^{16}$

A professora da Universidade de Coimbra, Márcia Mieko Morikawa, diz que a denominação internacional desses deslocados internos é internally displaced persons - IDPs, com representantes na ONU. ${ }^{17}$ Não se trata de nova forma de refugiados, mas simplesmente de sua visibilização - visibilidade de opressão, cabendo lembrar que, conforme estudos do ex-representante da ONU para os IDPs, Francis Mading Deng, em 1982, o número de deslocados internos em onze países era de 1,2 milhões de pessoas; uma década mais tarde, $24 \mathrm{mi}-$ lhões; atualmente [o dado é de 2003], a cifra ultrapassa já os 25 milhões em cinquenta países. ${ }^{18}$

Essas pessoas perseguidas e humilhadas não ultrapassam fronteiras, permanecem sob a pressão, e não sob a proteção, do Estado de origem. Nem sempre tais Estados se negam a protegê-las, mas a desestruturação social e econômica, simplesmente impede qual-

12 ONU, Genebra, 28 jul. 1951.

13 Organização da Unidade Africana.

1410 set. 1969, entrando em vigor apenas em 1974.

15 Organização dos Estados Americanos, 1984.

16 Nona conclusão do Colóquio, integrado na Declaração de Cartagena.

17 MORIKAWA, Márcia Mieko. Deslocados Internos: Entre a Soberania do Estado e a Proteção Internacional dos Direitos do Homem. Coimbra: Coimbra Ed., 2006. p. 15.

18 Id., p. cit. 
quer forma de assistência. Há Estados paralelos dentro do Estado, gerando o caos. E, sob o aspecto internacional, não são os deslocados internos considerados refugiados, nos termos da Convenção de 51. A não ser que, ultrapassada a fronteira, uma interpretação ampla seja aplicada ao fugitivo, possibilitando assistência e proteção temporárias. Sequer o princípio do non-refoulement pode ser invocado, muitas vezes!

3. Vale distinguir entre exilados, asilados e apátridas. ${ }^{19}$

3.1. Quando buscamos, nos manuais de Direito Internacional Público, a definição de exílio, nada encontramos. Até mesmo no Dicionário Prático do Direito Humanitário, ${ }^{20}$ de Françoise Bouchet-Saulnier, nos deparamos com a rubrica Refugiados, ${ }^{21}$ e no índice alfabético, vocábulos como apátrida, ${ }^{22}$ asilo, ${ }^{23}$ exodo.$^{24}$ Mazzuoli $^{25}$ examina a condição jurídica do estrangeiro, e nesta seção de seu Curso, trata de Extradição, Asilo territorial e asilo diplomático e refúgio. ${ }^{26}$

É interessante observar que, em obra coletiva, ${ }^{27}$ há inúmeros trabalhos sobre refugiados e asilo, com clara definição de cada espécie jurídica examinada. E há todo um artigo tratando do exílio (!) de Rui Barbosa. ${ }^{28}$ Nada mais justo, então, nesse contexto, que localizemos referências a exílio, ${ }^{29}$ a partir da dicionarização do termo: em Buarque de Holanda, Aulete, Antenor Nascentes e Houaiss encontramos exilado, "quem

19 As referências a seguir encontram-se, basicamente, no artigo intitulado Breves anotações sobre os Direitos dos Refugiados. In: AZEVEDO, Tupinambá Pinto de (Org.). Direito Internacional Penal e a Proteção dos Direitos Humanos. Porto Alegre: Dom Quixote Ed., 2013. p. 15-70. ver no caso específico, p. 28 e seguintes.

20 BOUCHET SAULNIER, Françoise. Dictionaire pratique du Droit Humanitaire. Paris: Éd. La Découverte, 1998.

21 Réfugiés, p. 326-334.

22 Apatride, p. 28.

23 Asile, p. 33.

24 Exode, ver Déplacement de population, p. 128.

25 MAZZUOLI, Valerio de Oliveira. Curso de Direito Internacional Público. 2. ed. São Paulo: Revista dos Tribunais, 2007.

26 Ibid., p. 603-620.

27 ARAÚJO, Nádia; ALMEIDA, Guilherme Assis de (Coord.). O Direito Internacional dos Refugiados: uma perspectiva brasileira. Rio de Janeiro: Renovar, 2001.

28 LACOMBE CAMARGO, Margarida Maria; MACHADO ALEXANDRE, Cristina Vieira. O exílio de Rui Barbosa. In: Id., ibid., 2001, p. 127-146.

29 ALMEIDA, Guilherme de Assis. Asilo e não-violência. In: Id., ibid., 2001, p. 169-175. 
deixou, de forma voluntária ou forçosa, sua terra natal". 30

Guilherme Almeida parte do dicionário e traz o enquadramento do exílio para a área jurídica. "Exílio" - diz "significa estar distante, fora de sua terra natal." Mas é preciso discutir a diferença, entre o exílio voluntário e o forçoso. "Devido aos exilados, que foram gerados pela Ditadura Militar de 1964, identificamos o exilado como quem deixou forçosamente, o seu país. Divergências à parte, o fato é que exilado é quem vive distante de seu país, por (1) vontade própria ou (2) forçosamente." E Guilherme Almeida conclui: "Na primeira alternativa, será considerado um exilado migrante, na segunda, será considerado um exilado stricto sensu, se for recebido do mesmo modo que um estrangeiro, recebendo proteção jurídica, do país que o acolheu, será considerado um asilado. ${ }^{{ }_{31}}$ Em nota de rodapé ${ }^{32}$ vem o esclarecimento de que, asilado, "no amplo sensu [...] engloba asilado político e refugiado."

A obra de Edward Said, Reflexiones sobre el exílio ${ }^{33}$ - não por acaso, aliás, as memórias de Said, publicadas em 1999 (tradução brasileira de 2004), intitulam-se Fora do Lugar ${ }^{34}$ - destaca o angustiante processo de construção de uma identidade, no mundo convulsionado de nossa época (ele nasceu em 1935, em Jerusalém - Palestina), e seu país foi substituído, treze anos depois, pelo Estado de Israel. Daí a peregrinação pelo Egito, Líbano, Estados Unidos. Seria ele um exilado, asilado ou refugiado?

Ele mesmo trata de resolver essas questões. "Se bem qualquer pessoa impedida de regressar a seu lugar seja um exilado, podem se estabelecer algumas distinções entre exilados, refugiados, expatriados e emigrados. ${ }^{{ }^{35}}$ Senão, vejamos: "O exílio nasceu da antiga prática do desterro. Uma vez desterrado, o exilado vive uma existência anômala e miserável com o estigma de ser um estrangeiro." É interessante a observação de Said, quanto aos refugiados, que seriam "uma criação do Estado do século XX." Pois, a " palavra refugiado se converteu em um termo político que faz pensar em grandes massas de pessoas inocentes e desconcertadas que requerem ajuda internacional urgente, enquanto que exi-

30 Id., p. 171.

31 Id., ibid., p. 171.

32 Id., ibid., n. 3.

33 SAID, Edward. Reflexiones sobre el exilio. Barcelona: Editorial Debate Ed. Mondadori, 2005.

34 SAID, Edward. Fora do lugar: memórias. São Paulo: Cia. das Letras, 2004.

35 SAID, Reflexiones sobre... p. 188. 
lado leva consigo, creio eu, um toque de solidão e espiritualidade." ${ }^{36}$

No mesmo sentido, Flávia Shiling. ${ }^{37}$ Em texto dedicado a Paulo Schilling, seu pai, exilado no Uruguai e na Argentina, de 1964 a 1980, Flávia faz rápido comentário sobre o termo exílio. ${ }^{38}$ "Exilados, refugiados, migrantes, desterrados, desenraizados, ${ }^{39}$ deslocados"- escreve Flávia. E prossegue, com palavras de Bauman: "Indivíduos frágeis, destinados a conduzir suas vidas numa realidade porosa, sentem-se como patinando sobre gelo fino" ${ }^{40}$ Lembra, então, da primeira edição do Fórum Social Mundial (Porto Alegre-RS), ocasião em que ouviu, de expositora boliviana, a reivindicação do direito ao enraizamento como direito humano. Um direito de não ser forçado à migração, "de não ser expulso ou deslocado de sua terra". Seriam exílios forçados ou voluntários? Significando "estar fora do lugar conhecido" - e aqui voltamos a Said. Mas também podemos con- tinuar dentro de nosso lugar, nosso país, o que levou à invenção, no Uruguai, da expressão inxílio, na experiência vivida pelos que ficam, nas ditaduras, com a clara sensação de estarem exilados em sua própria pátria. Ao mesmo tempo, este estranhamento, este olhar partido, este deslocamento, pode ser visto em sua positividade e como um elemento fundamental para o conhecimento. Dentro ou fora, Flávia remonta novamente a Bauman, comentando Derrida: "em vez de ser sem pátria, o segredo é estar à vontade em muitas pátrias, estar em cada uma ao mesmo tempo dentro e fora, combinar a intimidade com a visão crítica de um estranho, envolvimento com distanciamento."

$\mathrm{O}$ exilado sempre rompe regras, e isso não é uma escolha, mas a busca dos códigos profundos da cultura para onde se vai. Se há retorno, sempre esperado, o ex-exilado perceberá que, em seu próprio país de origem, sentirá al-

36 Edward Said: "E os expatriados? Estes vivem voluntariamente em um país estranho, normalmente por razões pessoais ou sociais. Hemingway e Fitzgerald não foram obrigados a viver na França. Os expatriados podem compartir a solidão e o estranhamento do exílio, mas não sofrem suas rígidas proscrições.”(op. cit., p. 188).

37 SHILLING, Flávia. E o exílio? Boletim do IBCCrim, ano 22, n. 263, São Paulo, out. 2014. p. 16.

$38 \mathrm{O}$ texto do IBCCrim é breve parte do memorial da livre-docência, defendido por Flávia Schilling na Faculdade de Educação da USP, em 2012.

39 Há dois famosos escritos de, Simone Weil, sob o título geral de $O$ desenraizamento, merecendo atenção o fato de que o primeiro texto é $O$ enraizamento, e o outro, $O$ desenraizamento operário. ver em BOSI, Ecléa (Org. Weil). Simone Weil: A Condição Operária e Outros Estudos Sobre a Opressão. Rio de Janeiro: Paz e Terra, 1979.

40 BAUMAN, Zygmunt. Modernidade líquida. Rio de Janeiro: Jorge Zahar, 2001. p. 239. 
gum estranhamento, ele, que já vivenciara o estranhamento do próprio exílio. Provavelmente, ponto em comum entre exilados e refugiados. Só que, estes nem sempre terão o lastro do conhecimento adquirido por meio da educação, do ensino, do estudo universitário. Com mais intensidade, refugiados serão estranhos, onde acolhidos. Não se esperam deles aumento de liberdade e da criação.

É disso que fala, também, Said, se apresentando como um exilado no Egito, no Líbano e nos Estados Unidos. E, da mesma forma, Bauman, quando retorna à sua terra natal, Praga, para receber o título de doutor honoris causa, na universidade. Perguntam-lhe qual hino deve ser tocado durante a cerimônia, atendendo a antigo costume universitário. Polônia, país de seu nascimento, ou Grã-Bretanha (Inglaterra), para onde foi viver quando lhe tiraram o direito de ensinar, na Polônia? Eis o dilema de um exilado ou ex-exilado. A resposta final foi: o hino da Europa. ${ }^{41}$ Como disse Bauman, com essa escolha "tirava da pauta uma identidade definida em termos de nacionalidade - o tipo de identidade que me foi negado e tornado inacessível". ${ }^{42}$ Mais: "até agora não existe um órgão europeu com a autoridade de emitir ou recusar um passaporte europeu, e assim conceder ou negar o direito de nos autodeterminarmos europeus." ${ }^{43}$

3.2. Temos, depois, os emigrantes: "gozam de uma ambígua condição. Tecnicamente, um emigrado é qualquer pessoa que emigra a um novo país. Nesta questão a eleição é certamente uma possibilidade. Os funcionários coloniais, os missionários, os técnicos especializados, os mercenários e assessores militares cedidos podem em certo sentido viver no exílio, mas não foram desterrados." Há que haver cuidado em distinções como exilado e emigrante: "Os colonos brancos da África, algumas zonas da Ásia e Austrália podem ter sido exilados, mas enquanto pioneiros e construtores de uma nação perderam a etiqueta de exilado." ${ }^{\prime 4}$ Eram emigrantes.

3.3. Finalmente, os apátridas. Gustavo Pereira publica, nos Cadernos IHU Ideias, da Unisinos, artigo sobre essa temática. ${ }^{45}$

41 Ode à Alegria (da 9a Sinfonia), de Ludwig van Beethoven.

42 BAUMAN, Zygmunt. Identidade. Rio de Janeiro: Jorge Zahar Editor, 2005. p. 16.

43 Id., ibid., p. 16.

44 Id., ibid., p. 188.

45 PEREIRA, Gustavo Oliveira de Lima. Apátridas e refugiados: direitos humanos a partir da ética da alteridade. Cadernos IHU, n. 181, ano 10. São Leopoldo, UNISINOS/ RS, 2012. ver, do mesmo autor, A pátria dos sem pátria - direitos humanos \& alteridade. Porto Alegre: Ed. Ritter, 2011.; e Direitos Humanos e Hospitalidade: a proteção internacional para apátridas e refugiados. São Paulo: Atlas, 2014. 
"No plano do direito internacional dos direitos humanos" - diz ele - "há uma diferenciação entre a figura do apátrida e a do refugiado que é necessário diferenciarmos." ${ }^{46}$ Consabidamente, pessoas consideradas sem pátria, são os apátridas. Uma definição clássica. Tata-se de espécie de circunstância existencial, capaz de repercutir de modos diversos na existência do ser humano sem nacionalidade. Repercute de inúmeras formas na vida do ser humano desprovido de nacionalidade. "Dificuldades de acesso à saúde pública, impossibilidades imigratórias e exclusão de determinados atos da vida civil." A apatridia ocorre por critérios discricionários (como foi o caso da II Guerra Mundial, quando o primeiro ato dos nazistas contra os judeus consistiu na retirada de cidadania alemão) ou por critérios do rótulo de nacionalidade de cada nação. Segundo a sistematização internacional os critérios de atribuição de nacionalidade compreendem o jus soli $\mathrm{e}$ o juz sanguinis. Pelo primeiro, atribui-se nacionalidade a quem nasce em determinado território. No segundo, "países que só admitem cidadania de filhos de seus nacionais, a territorialidade não confere nacionalidade." O risco que decorre dessa classificação está na possibilidade, cada vez mais comum, de nascimento de alguém em país estrangeiro, que adota o critério do sangue, sendo que o casal gerador do filho é oriundo de país com o específico critério do solo, para fixar a nacionalidade. Surge, então, a figura do apátrida, a não ser que exista, no país de nascimento da criança, norma especial resolvendo essa questão, como ocorre no Brasil. Desde 2007, com a Emenda Constitucional n. 54, temos ambos os sistemas, sendo o critério do solo prevalente, mas não único.

Alguns entendem que não há diferença entre o apátrida e o refugiado, mas isso não se confirma normativamente. $\mathrm{O}$ refugiado tem sua situação normalmente resolvida, com visto de permanência no país para onde migra; o apátrida é aquele que foge para outro país, mas não traz documentos que o identifiquem. É um indocumentado. Não existe, e não tem garantia de permanência no país que pretende adotar. $\mathrm{O}$ órgão da ONU responsável pela proteção dos refugiados e apátridas é o mesmo, Alto Comissariado das Nações Unidas para Refugiados (ACNUR). Em 2012, havia cerca de 12 milhões de apátridas espalhados pelo mundo. E o ACNUR prestava assistência humanitária a mais de 35 milhões de refugiados, apátridas e deslocados internos, no mundo. ${ }^{47}$

46 Id., p. 31.

47 A ONU pretende resolver a situação dos apátridas, pelo menos em dez anos - é a manchete divulgada em 6 de novembro de 2014 (Jornal O Sul, Porto Alegre, p. 7): "O ACNUR lançou ontem" - diz o texto - "uma campanha que apela aos governos dos países para que tomem uma série de medidas para colocar fim ao problema da apatridia 
Essa assistência é insuficiente, pois além do combate interno em certos países, contra seus próprios compatriotas - eis a figura do deslocado interno -, todos sabemos da política de combate à imigração considerada ilegal na Europa, pela diretiva de retorno, também conhecida como diretiva da vergonha, e da política imigratória dos Estados Unidos. Solicitantes de refúgio, desde logo, são levados à prisão, como consequência do atual combate ao terrorismo.

A tese sustentada por Gustavo Pereira é no sentido de que necessitamos de uma crítica aos pressupostos dos direitos humanos. A questão dos apátridas e refugiados, diz ele, não está somente nas possibilidades jurídicas de se pensar mecanismos de proteção internacional para este grupo de pessoas. "Está em pensar ou identificar como opera a violência da racionalidade ocidental que torna possível suportar a ideia de existir um ser humano à margem da proteção jurídica por não ter uma nacionalidade - é o que chamo de a ficção da nacionalidade." ${ }^{48}$

E pergunta: "Como é possível os direitos humanos estarem absolutamente sustentados a partir da ideia de naciona- lidade? Como é possível suportarmos isso?" O problema é que se todo ser humano tem direito à nacionalidade, essa vinculação ao Estado-nação pode, em seu extremo, levar a regimes xenófobos. Em lugar disso, Gustavo Pereira coloca uma racionalidade apátrida, uma racionalidade para além da ideia de cidadania, para bem além da ideia de cidadão do mundo, pois essa ideia ainda estaria contaminada pela noção de soberania. "Uma racionalidade em que o outro seja reconhecido pela concretude de sua singularidade, e não pela ideia de cidadania." ${ }^{49}$

Uma utópica proposta de superação da ideia de Estado-nação? Consabidamente, os Estados europeus modernos, surgidos no século XIX, trouxeram para a história a noção de soberania. Tais Estados-nação inauguram forma sui generis de organização política. A soberania é princípio fundamental da nova instituição, concentrando "as atribuições do poder público em um único agente e, consequentemente, a possibilidade que o imperium sobre um determinado território reste sintetizado naquele mesmo agente: o Estado." ${ }^{50} \mathrm{Se}$ estamos falando do Estado, como forma

em até dez anos. Atualmente, segundo o órgão, pelo menos 10 milhões de pessoas, em todo o mundo, são apátridas - pessoas que, por diferentes motivos, não têm nacionalidade. Com isso, muitas vezes não têm acesso a direitos básicos."

48 PEREIRA, 2012, n. 181, p. 33.

49 Id., ibid., 2012, n. 181, p. 7.

50 TEIXEIRA, Anderson Vichinkeski. Teoria universalista do direito internacional. São Paulo: WMF Martins Fontes, 2011., p. 71. Em nota de rodapé n. 4, desta mesma página, 
de organização política, que sucedeu a inúmeras formas anteriores, afastamos os riscos de uma utopia: basta(m) no$\mathrm{va}(\mathrm{s})$ forma(s) de organização política. Mas isso não afasta a dificuldade, até aqui encontrada, de superação do Estado-nação.

Veja-se o que propõe Marcelo Neves, ao falar de abertura da estalidade, hipótese em que se teria um modelo que não parte de uma única perspectiva, fosse "a estatal ou a internacional abrangente". ${ }^{51} \mathrm{E}$ sim de ambas, falandose em soberania interna e soberania externa. A chamada abertura da estatalidade, traria consigo, na proposta do autor, "uma interpenetração entre ordem estatal e internacional" (aqui, Neves adota tese de Langer Stefan), exigindo "progressivamente um aprendizado e um intercâmbio entre as experiências com racionalidades específicas nas duas perspectivas, a estatal e a internacional". 52

Por outro lado, Teixeira defende nova premissa de trabalho, a partir da ideia de pluriversalismo. A uma, trazendo o conceito de direito supranacional mínimo, ${ }^{53}$ última instância político-jurídica internacional. O desenvolvimento do sistema estaria centrado "não mais na noção de Estado nacional, mas na concepção de espaço regional" ${ }^{54}$ Entenda-se, sinteticamente, espaço regional, e não comunidade regional como forma de organização que depende de processos de integração política capazes de desenvolvimento adequado em seu interior. Todavia, é exigível um fundamento de legitimidade, indo além das vontades políticas presentes nas circunstâncias conjunturais ou dos comandos do mercado internacional. Teixeira busca legitimidade do espaço regional, na supremacia de uma tradição históricocultural. Tendo-se nesse referencial um princípio-guia. É de tal supremacia que emana o reconhecimento. Como ficaria, nesse contexto, a soberania nacional? Em uma nova soberania, marcadamente relativizada. Por fim, a proposta de Teixeira se completa com

Teixeira traz à colação o magistério de FIORAVANTI, Maurizio (Org.), Lo Stato moderno in Europa. Roma/Bari: Laterza, 2002, p. 7-8: "O Estado moderno europeu evidentemente contou, no início do seu percurso, com uma primeira forma, na qual se encontraram ao máximo alguns elementos que vieram a ser próprios das formas que seguiram, inspiradas pelo princípio-guia da soberania política: a tendência do senhor em se colocar no centro de um dado território ou ao início do mesmo processo de concentração dos poderes de imperium." 51 NEVES, Marcelo. Transconstitucionalismo. S. Paulo: WMF Martins Fontes, 2009. p. 134

52 Id., ibid., p. 134.

53 ZOLO, Danilo. Il signore dela pace. Roma: Carocci, 1998.

54 TEIXEIRA, 2011, p. 292. 
uma estrutura jurisdicional adequada ao espaço regional. ${ }^{55}$

A duas, reconhecimento dispensa reconciliação. Basta admitir a possibilidade de, através do reconhecimento entre espaços regionais, alcançar-se a estabilidade. Temos, portanto, um contexto pluriversalista, aberto a um globalismo pluriversalista articulado em espaços regionais. ${ }^{56}$

E a estrutura jurisdicional adequada? Kelsen defendia como principal instrumento da ordem internacional, uma corte internacional (e não um governo mundial). "Raramente um Estado recusou-se a executar a decisão de uma corte a qual tenha reconhecido por tratado. A ideia de Direito, apesar de tudo, continua sendo mais forte que qualquer outra ideologia de poder." 57 O modelo trazido por Teixeira oferece algumas variantes, na impossibilidade observada nos modelos atuais, de cortes jurisdicionais, instituições políticas, sem apelo às ideologias. Teríamos, de logo, modelo incorporado por cada Estadonação; a corte daria acesso a indivíduos, a cidadãos, diante de pretensão resistida, improvidos os pedidos nas instâncias do Estado, recorrendo perante a Corte do Espaço Regional, cujos acórdãos teriam efeitos internos imediatos; por fim, se a alegada violação de direito fundamental for mantida, na Corte do Espaço Regional, um último recurso seria possível, perante o Tribunal Supra(Inter)nacional. $\mathrm{O}$ autor busca subsídios no modelo da União Europeia. As diretivas comunitárias têm eficácia perante os ordenamentos internos dos Estados membros. Fala-se, em tal sistema, do princípio da predominância do direito comunitário.

Aí está uma proposta jusfilosófica em prol de globalismo pluriversalista. Seria viável, inclusive para resolução da apatridia?

\section{PACHAMAMA E GAIA: UM ECOLOGISMO CONSTITUCIONAL/ CONVENCIONAL}

1. É hora de falar sobre o ambiente. Sejamos sintéticos. Sempre houve preocupação com o habitat, com o lugar onde se vive. Mas custamos a compreender que o ambiente pudesse se tornar impróprio para a vida - se há animais em extinção, por que não haveria homens em extinção, morando em certos locais determinados?

Só começamos a pensar em um direito ambiental na segunda metade do

55 Ver sobre espaços regionais, na obra de TEIXEIRA (2011), II Parte, item 2.3.

56 TEIXEIRA, 2011, p. 294.

57 KELSEN, Hans. Compulsory Adjudication of International Disputes. American Journal of International Law, V. 37, n 3, 1943. p. 399. 
século XX. No Brasil, na década dos 80 . A Constituição atual nos assegura um ambiente ecologicamente equilibrado, $\mathrm{e}$ o desenvolvimento infraconstitucional de normas ambientais é conhecido em grande parte do mundo. Inclusive, colocamos na Carta brasileira um Título VIII - Da Ordem Social, e dedicamos o Cap. VI ao Meio Ambiente. O art. 225 é exemplar. Em 1998, editamos a Lei n. 9.605 , tipificando crimes ambientais, com especial proteção à fauna, flora, ao ordenamento urbano e ao patrimônio cultural, à poluição e alguns outros crimes específicos.

Desde logo, podíamos perceber que em Estado federativo, como o nosso, há conflitos de competência jurisdicional, em casos em que o dano ambiental ocorre em mais de um Estado: rios que atravessam vários deles, como o São Francisco, biomas que não se limitam a um único Estado da Federação, etc. E nos deparamos com a realidade das atividades poluidoras que, provenientes de uma margem de fronteira, produz seus efeitos nocivos em país vizinho. Conhecemos, não faz muito, o caso das papeleras, colocando em choque Uruguai e Argentina. ${ }^{58} \mathrm{O}$ ambiente é internacional, por natureza.

Outro aspecto exige atenção: a tutela ambiental surgiu como forma de proteção ao ser humano, individualmente considerado. É a partir de bens jurídicos pessoais, como a saúde, a vida, o patrimônio, que chegamos à proteção de recursos naturais (água, solo, florestas, fauna, pesca, minérios). Trata-se da visão homocêntrica da proteção ambiental. Num segundo momento, a autonomia jurídica da disciplina traz a preocupação com a extensão das normas alcançando as gerações futuras. É a visão homocêntrica-intergeracional.

Finalmente, discute-se a natureza em si mesma. É a visão biocêntrica. A esta altura, já se debate acaloradamente a visão ecocêntrica (proteção dos próprios ecossistemas e seus componentes abióticos, como rios, lagos, montanhas, pântanos, etc.). Vejam que, na Lei 9.605/98, a poluição é vista como mal em si, e a proteção da fauna e flora independem de fatores utilitários... Essas novas visões, através da dinâmica social, dão base a teorias bem estudadas na física, por exemplo. Nessa área de conhecimentos surgiu a Teoria de Gaia, de James Lovelock ${ }^{59}$ cientista inglês. Sustentava que a terra era um organismo vivo, reagindo às ameaças que surgem para maximizar as chances de sobrevivência da vida. Gaia é terra, em grego. Era a Deusa-mãe do planeta. O papel da humanidade, nesse contexto, seria insignificante.

58 BERTONI, Liliana (Coord.). Las papeleras en cuestión - un recorrido por el derecho ambiental e internacional de La Haya al Mercosur. Buenos Aires: Eudeba, 2010.

59 LOVELOCK, James. The revenge of Gaia. Why the Earth is Fighting Bacak: and How We Can Still Save Humanity. Londres: Penguin Books, 2006. 
Trazendo à colação o neoconstitucionalismo da América Latina, Zaffaroni ${ }^{60}$ menciona La Pachamama, espécie de deusa protetora universal, cujo nome vem de línguas originárias dos Andes, e significa Terra, ou mundo. É fácil perceber a similitude entre Pachamama e Gaia, palavras que aludem a um organismo vivo. Ambas reagem a ameaças de sobrevivência da vida, em todos os seus aspectos. Como é comum entre manifestações ancestrais, Pachamama pede reciprocidade, vindo daí as expressões rituais de culto. Por seu lado, Gaia se mostra mais sofisticada, fruto de estudos científicos, da física contemporânea. Não promovemos rituais, mas Gaia e Pachamamas expressam a mesma ideia.
Inclusive em relação a essas duas hipóteses, que em verdade são uma só, o corolário final é uma ética especial. O novo paradigma decorrente de Gaia-Pachamama é o reconhecimento dos direitos de todos os seres, os quais compartem com os humanos, a Terra. A invocação da Pachamama é acompanhada da regra básica ética do sumak kawsay, "expressão quíchua que significa bem viver ou pleno viver e cujo conteúdo não é senão a ética que deve reger a ação do Estado e conforme à qual devem se relacionar as pessoas entre si e, em especial, com a natureza". ${ }^{61}$

As recentemente promulgadas Constituições do Equador e da Bolívia mencionam, expressamente, La Pachamama e o sumak kawsay (bem viver). ${ }^{62}$

60 ZAFFARONI, Eugenio Raúl. La Pachamama y el Mundo. B. Aires: Ed. Colihue/Ed. Madres de Mayo, 2012.

61 Id., ibid., 2012, p. 111.

62 Ver Preâmbulo da Constituição da República do Equador (2008): “Celebrando a la naturaleza, la Pacha Mama, de la que somos parte y que es vital para nuestra existencia... Adiante, faz referencia ao sumak kawsay: “: Una nueva forma de convivencia ciudadana, en diversidad y armonía con la naturaleza, para alcanzar el buen vivir, el sumak kawsay. O Capítulo VII se refere a "Derechos de la naturaleza", desse modo "reconoce la cuestión medioambiental como propia de la naturaleza y a ésta como titular de derechos." 109 Art. $71^{\circ}$ : "La naturaleza o Pachamama, donde se reproduce y realiza la vida, tiene derecho a que se respete integralmente su existencia y el mantenimiento y regeneración de sus ciclos vitales, estructura, funciones y procesos evolutivos. // Toda persona, comunidad, pueblo o nacionalidad podrá exigir a la autoridad pública el cumplimiento de los derechos de la naturaleza. Para aplicar e interpretar estos derechos se observarán los principios establecidos en la Constitución, en lo que proceda. // El Estado incentivará a las personas naturales y jurídicas, y a los colectivos, para que protejan la naturaleza, y promoverá el respeto a todos los elementos que forman un ecosistema."

Preâmbulo da Constituição Política do Estado boliviano (2009): “Cumpliendo con el mandato de nuestros pueblos, con la fortaleza de nuestra Pachamama y gracias a Dios, 
"Deste modo" - escreve Zaffaronni - "o constitucionalismo andino deu o grande salto do ambientalismo à ecologia profunda, i. é, a um verdadeiro ecologismo constitucional. ${ }^{\prime 33}$ À luz da nova pirâmide, ${ }^{64}$ teríamos um ecologismo constitucional/convencional.

Digamos singelamente: o direito ambiental não é apenas internacional, mas sobretudo deve ser visto sob pontode-vista holístico, para que percebamos que não é possível destruir o ambiente, sob o pretexto de dominá-lo.

\section{REFUGIADOS E DESLOCADOS AMBIENTAIS?}

1. O mote que está na moda é o das mudanças climáticas!
Os chamados desastres naturais estão à vista de todos, assim como o avanço da desigualdade e da pobreza mundial. Nas palavras de Ulrich Beck, tais características "Son riesgos de la modernización. Son un producto global de la maquinaria del progreso industrial y son agudizados sistemáticamente con su desarrollo ulterior." ${ }^{\circ 5}$

Na década de 80 as evidências científicas relacionadas às emissões de gases de efeito estufa, provenientes das atividades humanas com mudança do clima global, começaram a despertar a preocupação pública. Após várias conferências internacionais sobre o tema, em 1990, a Assembleia Geral das Nações Unidas respondeu a esses apelos, estabelecendo o Comitê Intergovernamental de Negociação para a Convenção-Quadro sobre Mudança do Clima (INC/FCCC). ACon-

refundamos Bolivia." Art. 33: "Las personas tienen derecho a un medio ambiente saludable, protegido y equilibrado. El ejercicio de este derecho debe permitir a los individuos y colectividades de las presentes y futuras generaciones, además de otros seres vivos, desarrollarse de manera normal y permanente." Art. 34: “Cualquier persona, a título individual o en representación de una colectividad, está facultada para ejercer las acciones legales en defensa del medio ambiente, sin perjuicio de la obligación de las instituciones públicas de actuar de oficio frente a los atentados contra el medio ambiente. 63 Id., ibid., 2012, p. 111.

64 Ver GOMES, Luiz Flavio; VIGO, Rodolfo Luis. Do Estado de Direito Constitucional e Transnacional: Riscos e Precauções. São Paulo: Ed. Premier Máxima, 2008; MAZZUOLI, Valerio de Oliveira. O controle jurisdicional da convencionalidade das leis. (Col. Direito e Ciências Afins, v. 4.). São Paulo: Revista dos Tribunais, 2009; MAZZUOLI, Valerio de Oliveira; GOMES, Luiz Flávio. Direito Supraconstitucional: Do Absolutismo ao Estado Constitucional e Humanista de Direito. São Paulo: Revista dos Tribunais, 2010; NEVES, Marcelo. Transconsitucionalismo. São Paulo: Martins Fontes; 2009.

65 BECK, Ulrich. La sociedad del riesgo. Barcelona: Paidós, 2002. p. 28. 
venção foi adotada em maio de 92, em Nova Iorque, entrando em vigor em 94. Os compromissos mais fortes devem ser cumpridos pelos países desenvolvidos, mas são justamente muitos desses que se negam a ratificar a Convenção.

$\mathrm{O}$ aquecimento global derivado da emissão de gases de efeito estufa é problema evidente de nossa pós-modernidade. Daí o estímulo à produção de energia que não utilize combustíveis fósseis - busca-se o aperfeiçoamento do uso de biocombustíveis. E é nesse cenário que ocupa o centro o princípio do desenvolvimento sustentável. Eduardo Viegas, ${ }^{66}$ do Ministério Público gaúcho, sustenta até que o desenvolvimento sustentável é não uma regra jurídica, não um princípio, mas um sobreprincípio, valendo-se da teorização de Humberto Ávila, ${ }^{67}$ que acrescenta a esses dois tipos de normas, outros dois: o postulado e o sobreprincípio. Este, seria simplesmente, princípio constitucional "em posição axiológica diferenciada, porquanto, como sobreprincípio, sua incidência não pode ser afastada na hipótese real de conflito com outras normas jurídicas, ainda que também estejam inscritas na Constituição. Enteder-se o contrário é conceber a possibilidade de, licitamente, ocorrer desenvolvimento insustentável. "68

2. Confluem, lamentavelmente, a questão dos refugiados e a dos desastres ditos naturais, mas que em grande escala decorrem de ações humanas. Cria-se, então, a figura do refugiado ambiental, conceito introduzido por Lester Brown, durante os anos 70 (dissemos, anos 70 !). O conceito é dado por Essam El-Hinnawi, professor do Centro Nacional de Pesquisa Egípcio, em 1985: refugiados ambientais são "aquelas pessoas que foram forçadas a abandonar o seu habitat tradicional, de forma temporária ou permanente, por causa de uma evidente perturbação ambiental (natural e/ou acionada por pessoas), que ameaça a sua existência e/ou afeta gravemente a qualidade da sua vida." ${ }^{69}$

Perturbações ambientais são, no caso, secas, erosão do solo, desertificação, inundações permanentes, ciclones, incêndios de floresta, além de fenômenos naturais decorrentes de terremotos e avalanches. Há dados que estimam, em 1995, cerca de 25 milhões de refugiados ambientais em todo o mun-

66 VIEGAS, Eduardo Coral. O desenvolvimento sustentável como sobreprincípio, In: BENJAMIN, Antonio Herman et al. (Coord.). Mudanças Climáticas, Biodiversidade e uso sustentável de energia. São Paulo: Imprensa Oficial, 2008.

67 ÁVILA, Humberto. Teoria dos Principios. São Paulo: Ed. Malheiros, 2014. 68 Id., loc. cit., 2008, p. 158.

69 Id., Environmental Refugees. Nairobi: United Natios Environment Programms, 1985. p. 4. 
do, contra 27 milhões decorrentes da aplicação pura e simples do Estatuto do Refugiado. A grande maioria nos países da África subsaariana.

Mesmo no Brasil, o problema da desertificação vem afetando inúmeras áreas, principalmente no nordeste, buscando as pessoas o abandono de suas terras, atrás do auxílio em outras regiões. Entre nossas missões, nesse contexto, está o combate ao aquecimento global.

Se olharmos ao nosso redor, com visão micro, teremos secas, enchentes, ciclones, no Rio Grande do Sul, e na primeira década do século XXI, segundo dados oficiais, "foram registrados 3.343 desastres naturais no Estado, um crescimento de $111 \%$ com relação à década anterior, de acordo com a Secretaria Nacional de Defesa Civil." "70 Vale dizer, a questão das perturbações ou desastres naturais estão à nossa porta, e tudo isso se relaciona com as mudanças climáti- cas..$^{71}$ Estas podem decorrer de desastres naturais, como no caso das erupções vulcânicas, ou de atividades humanas, que, fundamentalmente, provocam a emissão e acumulação excessiva de poluentes, como o dióxido de carbono, na atmosfera. Falamos, como já se disse, do efeito estufa. $\mathrm{O}$ aquecimento global recebeu, na ONU, a denominação de mudanças climáticas globais. Em verdade, há dois conceitos acerca das mudanças climáticas: o primeiro se refere a mudança no clima atribuída direta ou indiretamente, à atividade humana; ${ }^{72}$ o segundo, alude a qualquer mudança do clima, em decorrência da variabilidade natural ou da atividade humana. ${ }^{73}$

Em linguagem simples, o efeito estufa decorre de aquecimento da parte inferior da atmosfera, principalmente decorrente de dióxido de carbono e vapor de água, de modo que os raios do sol aqueçam a terra, mas impedem que uma

70 TELLES, Pedro. Desastres naturais e eleições no RS, Jornal Zero Hora, p. 32 (Primeiro Caderno), $1^{\circ}$ set. 2014. O autor do artigo é assessor de políticas públicas do Greenpeace. 71 Não por acaso, o Instituto O Direito por um Planeta Verde realizou, em seu $13^{\circ}$ Congresso Brasileiro de Direito Ambiental e $11^{\circ}$ Congresso Internacional de Direito Ambiental, realizados em São Paulo, de 27 de maio a $1^{\circ}$ de junho de 2007, extraordinárias propostas acerca do tema Mudanças Climáticas, Biodiversidade e Uso Sustentável de Energia. Daí a publicação, em dois alentados tomos, total de 1.974 páginas (!), obra com o mesmo título, contendo conferências de renomados profissionais e artigos de estudantes da graduação e pós-graduação.

72 Definição contida na Convenção Quadro das Nações Unidas sobre Mudança do Clima (1992).

73 Ver Painel Intergovernamental de Mudanças Climáticas (IPCC). MIRANDA, João Paulo Rocha de et al. O Direito Ambiental como Instrumento Mitigador das Queimadas na Amazônia Brasileira e das Mudanças Climáticas Decorrentes do Aumento 
parte do aquecimento retorne ao espaço. As nuvens seriam, então, responsáveis por esse efeito de estufa, tornando-se mais alta a temperatura da superfície terrestre. Há processos naturais que produzem esse efeito, mas consabidamente a atividade humana, pela queima de combustíveis fósseis, de onde emana o gás do óxido de nitrogênio e o Cloro-Fluor-Carbono (CFC), ou seja, o $\mathrm{CO}_{2}$, aumenta de modo considerável a temperatura. Fala-se, então, de furos no ozônio (a que está particularmente atingida a região do sul do Brasil, para mais uma vez exemplificarmos com algo que vivenciamos).

Agora mesmo, em 2012, tivemos no Rio Grande do Sul, aquele que teria sido a pior seca dos últimos 60 anos. Traduzido em cifras (nesta era de predomínio das ideias econômicas), teríamos prejuízo em torno de dois bilhões de reais, sobretudo no agronegócio. Conhecemos por aqui os fenômenos El niño e $L a$ Niña, aos quais os meteorologistas e cientistas da área atribuem o agravamento das tragédias em nosso Estado e em Santa Catarina. Com sensatez, Pedro Telles conclui seu artigo jornalístico, depois de lamentar a ausência no país de prioridades governamentais quanto às mudanças climáticas, dizendo que "em vez de medidas de prevenção efetivas, resta à população a ajuda humanitária depois que o estrago já foi feito." 74

Voltaríamos, então, à problemática dos refugiados ambientais, eis que restaria a busca de ajuda humanitária frente aos desastres ambientais? Certamente.

E como as perturbações ambientais, estão presentes em todas as partes do planeta, todos, indistintamente, devem ser ambientalmente educados para o enfrentamento deste que é, o maior desafio hoje enfrentado pela humanidade.

3. Referimos, já, providências da ONU, como o Comitê Intergovernamental de Negociação para a Convenção-Quadro sobre Mudança do Clima (INC/FCCC), com Convenção adotada em 1992 (Nova Iorque). E antes de comentarmos o Projeto de Convenção Internacional dos Refugiados Ambientais, desenvolvido por um grupo de especialistas da Faculdade de Direito e de Ciências Econômicas da Universidade de Limoges, na França, tendo à frente o Professor Michel Prieur, ${ }^{75}$ vale

das Emissões de Gases do Efeito Estufa. In BENJAMIN, Antonio Herman; LECEY, Eladio; CAPPELLI, Silvia. Mudanças Climáticas, Biodiversidade e Uso Sustentável de Energia. São Paulo: Imprensa Oficial, 2008. p. 830.

74 TELLES, 2014, p. 32.

75 Membro honorário da Faculdade de Direito e Economia de Limoges, presidente do Centro Internacional de Direito Ambiental Comparado e do Centro de Investigação Interdisciplinar em Direito Ambiental de Planejamento e Desenvolvimento (CRIDEAUCNRS-INRA). Prieur teve, aliás, papel ativo, na qualidade de expert junto ao Conselho 
resenhar o artigo de Juan Pablo Terminiello, publicado na obra Protección Internacional de Refugiados en el Sur de Sudamérica. ${ }^{76}$

3.1. Resulta no articulado a seguir.

A Convenção Marco das Nações Unidas sobre a Mudança Climática define-a como "uma mudança de clima atribuída direta ou indiretamente à atividade humana que altera a composição da atmosfera mundial e que se soma à variabilidade natural do clima observada durante períodos de tempo comparáveis". ${ }^{77}$ Há também os desastres naturais, cuja definição pode ser encontrada nas Diretrizes Operacionais do Comitê Permanente Inter-Agencial (IASC): "um sério transtorno no funcionamento de uma comunidade ou uma sociedade que causa perdas humanas, materiais, econômicas e ambientais generalizadas que desbordam a capacidade da comunidade afetada para fazer frente com seus próprios recursos."
Aí estão os perigos da natureza, capazes de provocar tais perigos. ${ }^{78}$

3.2. O deslocamento forçado associado à mudança climática deixou de ser simples ameaça, "e se coloca como um dos principais desafios humanitários do século XXI. ${ }^{79}$ São mais de 43 milhões de pessoas deslocadas, em consequência de mudanças climáticas e desastres naturais..$^{80}$

3.3. É de conhecimento público, e particularmente dos militantes do trabalho humanitário, o risco planetário que se acelera neste século, em decorrência da mudança climática. O impacto atingirá as costas marinhas, acelerendo "o derretimento dos glaciais, alterará os regimes das chuvas e, em consequência, a disposição da água e de terras cultivadas". ${ }^{81}$ Soma-se, ao exposto, a situação de Estados insulares oceânicos ou continentais (ilhas ou grupos de ilhas-arquipélagos), como Tuvalu, Kiribati, Maldivas, Mal-

da Europa, na elaboração da Convenção de Florença, hoje Convenção Europeia da Paisagem. Conferir Revue Européenne de Droit de l'Environnement: Limoges: CRIDEAU, 2003-3, no especial consagrado à Convenção Europeia da Paisagem. V. adiante.

76 TERMINIELLO, Juan Pablo. Los desastres naturales, el cambio climático y la protección de los derechos humanos. Realidades y desafíos frente al desplazamiento forzado. In: ABRAMOVICH, Víctor et al. Protección Internacional de Refugiados en el Sur de Sudamérica. Lanús (Argentina): Ediciones de la UNLa, 2012, p. 131-176.

77 Ver http://unfccc.int/resource/docs/convkp/convsp.pdf.

78 Ver IASC. Diretrizes Operacionais do Comitê Permanente entre Organismos sobre a proteção dos direitos humanos em situação de desastres naturais: Projeto fr Brookings-Bern sobre Deslocamento Interno: jun. 2006.

79 TERMINIELLO, 2012, p. 133.

80 Dados de 2011. Seriam 30 milhões em 2008, 17 milhões em 2009 e 42 milhões em 2010.

81 TERMINIELLO, 2012, p. 134. 
vinas ou Falkland, Ilhas Marshall, etc., sob risco de desaparecimento ou de se tornarem inabitáveis. A elevação do nível dos mares podem acarretar problemas de deslocamentos forçados e apatridia.

3.4. Qual tratamento se dará às pessoas deslocadas? O caso em tela não coloca em questão deslocados internos, e sim deslocados externos, ou seja, de pessoas que se deslocam além das fronteira do Estado de origem. Para quem permanece dentro das fronteiras do país de residência habitual, ao menos incidem direitos e garantias reconhecidas pelos direitos humanos internacionais e o direito internacional humanitário. Ou seja, não perdem os direitos da população em geral. A Convenção sobre o Estatuto dos Refugiados, de 1951, nada dispõe a respeito dos deslocados ambientais fora das fronteiras do Estado natal. Haveria verdadeiro limbo legal, ${ }^{82}$ ameaçando a vigência e respeito dos direitos dessas pessoas. Bastaria invocar os direitos humanos, de forma ampla?

3.5. Em verdade, mesmo em casos mais comuns, onde o deslocamento interno ocorre, e o externo sempre deixa a possibilidade da volta ao território de origem, as respostas, por ora, dificilmente virão em sede normativa atinente aos refugiados. Na comparação com populações engolfadas por conflitos armados, muitas dificuldades enfrentadas por desastres ambientais se mostram próximas: "perda ou separação do grupo familiar; perda da moradia; perda ou destruição documental e de propriedade; ameaça ao direito de viver, à integridade e segurança pessoal; exposição à violência sexual e de gênero, entre outras." ${ }^{83}$

3.6. Nesse contexto, têm relevância os pactos internacionais de direitos humanos, sobretudo com o advento das garantias decorrentes dos direitos econômicos, sociais e culturais (direito ao trabalho, à saúde, à educação, à alimentação). Destaque-se o reconhecimento, há pouco afirmado, do direito à água potável e ao saneamento. Agora, são direitos humanos essenciais. ${ }^{84}$

3.7. É preocupante o desrespeito à proteção dos direitos humanos das pessoas deslocadas por desastres naturais. Terminiello mostra esse desrespeito no Marco de Ação de Hyogo 2005-2015 (MAH), instrumento importante para implementar a redução do risco de de-

82 Expressão de COHEN,R./BRADLEY, M. Disasters and Displacement: Gaps in Protection. Journal of International Legal Studies, v. 1, 2010. Em TERMINIELLO, 2012, p. 135.

83 TERMINIELLO, 2012, p. 136. Ver http://www.unhcr.org//refworld/docid/4d8c998c2.html. 84 Ver ASSEMBLEIA GERAL DAS NAÇÕES UNIDAS. $O$ direito humano à água e o saneamento: A/64/L.63/Rev.1,26: jul. 2010. Em TERMINIELLO, 2012, p. 137, nota n. 18. 
sastre, adotado pelos Estados membros da ONU. O MAH propõe o aumento da resiliência ${ }^{85}$ das comunidades vulneráveis aos desastres, mas seu texto é bastante omisso quanto à redução de custos humanos e sociais dos desastres.

3.8. Merece especial atenção a advertência da Secretária-Geral da Federação Internacional de Sociedades da Cruz Vermelha e da Meia-lua vermelha: "Os desastres naturais atingem os pobres, e asseguram que estes continuem sendo pobres." "\$6 É natural que os pobres, sempre vulneráveis, tenham agravada a situação perante desastres naturais ou provocados. E outra particularidade dos riscos ampliados a que ficam expostos os deslocados: estão expostos, mulheres e crianças, a especiais situações de violência sexual (inclusive prostituição forçada) e por motivo de gênero. "Depois do tsunami que afetou grande parte do sudeste asiático (2004) e o terremoto do Haiti (2010)" - escreve Terminiello - "a violência sexual se converteu em uma das principais ameaças à vida e segurança das mulheres e meninas que haviam sobrevivido." ${ }^{\prime 7}$ Sobretudo em se tratando de residência nos acampamentos e centros de evacuação de deslocados internos. "Ali, onde a lei e a ordem se quebram, [...] as mulheres e se tornam mais vulneráveis ao sofrimento de violações de seus direitos, incluída a violência física e sexual." ${ }^{\prime 88}$

3.9. Atenção especial deve ser dada à proteção da propriedade da terra das comunidades campesinas e indígenas. Não se trata, apenas, de valor patrimonial, mas "da manutenção de instituições, culturas e tradições e promoção de seu desenvolvimento, de acordo com suas aspirações e necessidades." "\$9

85 Resiliência: conceito criado na psicologia, emprestado da física e se refere à capacidade humana de assumir com flexibilidade situações-limite e sobrepor-se a elas. Capacidade para adaptar-se a mudanças. Capacidade que um indivíduo ou uma população apresenta, após momento de adversidade, conseguindo se adaptar ou evoluir positivamente frente à situação. Em inglês, resilience (1824) Elasticidade; capacidade rápida de recuperação. Em latim, resiliens. Resiliência possui diversos significados para a área da física, psicologia, administração, ecologia e direito. Ver www.dicionarioinformal.com.br/resiliência; http://www.significados.com.br/resiliencia/.

86 Cherpitel, D. Breaking the cycle. Our Planet, v. 11, n. 3. (Disasters, 2002), ver em http://www.ourplanet.com/imgversn/113/cherp.html.

87 Id., ibid., 2012, p. 142, nota n. 30.

88 Declarações da porta-voz da Coalition for Assisting Tsunami Afected Women (CATAW). No site web Asia News, 26 jan. 2005.

89 ASSEMBLEIA GERAL DAS NAÇÕES UNIDAS. Declaração das Nações Unidas sobre os direitos dos povos indígenas. 2 out. 2006, A/RES/61/295.2007. 
3.10. Há diferença entre um desastre natural abrupto, como um terremoto que, em segundos, lança à rua milhares de pessoas, com problemas de moradia, e muitos outros, e a desertificação de um território, conjugada à mudança climática, que decorre de processo lento de anos ou décadas. Veja-se o aumento da temperatura média mundial, já prevista, com consequências funestas, principalmente para gente vulnerável, e instituições governamentais frágeis resultando da mudança climática lenta e gradual, com tensões sociais e políticas e conflitos armados. ${ }^{90}$

3.11. O ACNUR resistiu, até recentemente, a envolver-se em situação de deslocamento interno por desastres ambientais. Em 2005, essa agência, tratando dos deslocados internos, no marco da Reforma Humanitária, ${ }^{91}$ dizia: "o rol de liderança do ACNUR em três clusters (setores de resposta humanitária), não se aplicará quando o deslocamento interno for causado única ou substancialmente por desastres naturais". No mesmo documento afirmava não ter envolvimento com esse segundo grupo, "salvo em cir- cunstâncias excepcionais". ${ }^{92}$ Mas, há pouco tempo o ACNUR se tornou mais ativo, na área em discussão, demonstrando interesse em incluir em sua agenda, operações para assistência a deslocados por desastres naturais, como os casos do Paquistão, diante de inundações (2010), do Haiti (idem), da China (terremoto em 2008), de Myanmar, ciclone. Contudo, ainda há cautelas para tal envolvimento.

3.12. Se estivermos diante de deslocados internos em decorrência de desastre natural, em concurso com conflito armado, o marco legal de proteção a tais vítimas de desastre será complementado por normas do Direito Internacional Humanitário. E como tratar os deslocados externos, que fogem de desastres naturais e da mudança climática? Serão refugiados ambientais? Estão em limbo legal, pois não podem ser classificados como refugiados, sujeitos expulsão, deportação, detenção, apatridia. Como já foi dito anteriormente, não aparecem na Convenção de 1951, na Declaração de Cartagena, e em outras normativas. Sabidamente, refugiado é alguém que é perseguido ou com temor de sê-lo, por

90 Ver ASSEMBEIA GERAL DA ONU. A mudança climática e suas possíveis repercussões para a segurança: Informe do Secretário Geral, A/64/350, 11 set. 2009, p. 12. Em TERMINIELLO (2012), p. 149.

91 Fala-se de Reforma Humanitária para o processo desencadeado pela ONU, para melhoria da capacidade de respostas humanitárias, sob liderança do Direito Humanitário. 92 ACNUR, UNHCR. Role in IASC Humanitarian Reform Initiatives and in the Strengthening of the Inter-Agencie Collaborative Response to Internally Displaced Persons Situations, 20 set. 2005. 
motivo de raça, religião, nacionalidade, pertencente a determinado grupo social ou opiniões políticas. Em consequência, coloca-se fora de seu país e não pode ou não quer retornar. ${ }^{93}$ Nada sobre o que seria um refugiado ambiental, e como haveria proteção só em caso de um dos cinco motivos, sendo tal ou tais associados ao desastre ambiental, está clara a omissão legal quanto à pura razão ambiental. O ACNUR não aceita a definição ampliada ou regional de refugiado, da Declaração de Cartagena ("um determinado grupo social"), pois o grupo deveria estar conectado por característica fundamental, imutável, "que não seja o risco de persecução em si mesmo". ${ }^{94}$

3.13. Nos últimos anos, países latino-americanos têm aplicado interpretação ampla da definição de refugiado, de Cartagena, estendendo proteção a pessoas que tenham fugido dos efeitos de desastres naturais. Foi o que entenderam Peru e México, para o caso dos haitianos. ${ }^{95}$ Embora frágil e parcial a interpretação, por não aplicável diante de processos lentos de mudança climática, demonstra preocupação efetiva com tais deslocados.
Entre os esforços dos internacionalistas, crescem de importância normas de direitos humanos, onde mais facilmente, verbi gratia, se aceitaria o non refoulement. Mas é importante destacar que vivemos em época de políticas restritivas à migração internacional, refletindo-se em interpretações também restritivas das normas aplicáveis a refugiados.

\section{MUDANÇAS CLIMÁTICAS E DIREITO DOS REFUGIADOS}

1. Quando, no Brasil, foi promulgada a lei de crimes ambientais, ${ }^{96}$ e algumas omissões foram logo detectadas, o entendimento dos ambientalistas era no sentido de que fosse evitada a via legislativa, pois a simples presença, no Congresso Nacional, de projeto de lei ou medida provisória, a serem discutidas e votadas, criaria o risco de involução, retrocesso, quanto à lei recém vigente. ${ }^{97}$ É da mesma espécie o temor do ACNUR: propostas de renegociação da Convenção de 1951, "no momento

93 Convenção de 1951 , art. $1^{\circ}$.

94 ACNUR. Diretrizes sobre proteção internacional: "Pertencer a um determinado grupo social" no contexto do Art. $1^{\text {a}}(2)$ da Convenção de 1951 sobre o Estatuto dos Refugiados e/ou seu Protocolo de 1967, 2002. p. 14. Em Terminiello, 2012, p. 158.

95 TERMINIELLO, 2012, p. 161.

96 Lei n. 9.605/98.

$97 \mathrm{Na}$ verdade, entre os princípios ambientais há a proibição de retrocesso. Fala-se, também, na insuficiência, hipótese na qual a inexistência de normas que seriam mínimas para 
atual podem dar lugar a uma redução das normas de proteção do refugiado e inclusive comprometer todo o regime de proteção internacional de refugiados". ${ }^{98}$ A realização de eventos objetivando a atualização da Declaração de Cartagena (1984), nos 30 anos da normativa, permite melhores perspectivas, pois os países latino-americanos mostram-se comprometidos com a causa dos migrantes e dos refugiados. Aliás, nota-se que o ACNUR vem modificando sua visão, acerca dos deslocados por desastres naturais, como se pode constatar pela convocação do ACNUR, em Bellagio, Itália, 2011, acerca de Mudança Climática e Deslocamento. Sustentou, então, que "existe a necessidade de desenvolver um marco ou instrumento global guia que se aplique a situações de deslocamento externo, distintas das já cobertas pela Convenção de 1951, espe- cialmente o deslocamento que resulta dos desastres repentinos." ${ }^{\prime 9}$

2. Por fim, cabe registrar que o Brasil tem se destacado na proteção a refugiados e migrantes, com destaque para a proteção temporária. ${ }^{100}$

3. Vejamos o Projeto de Convenção Internacional dos Refugiados Ambientais. Desenvolvido por um grupo de especialistas da Faculdade de Direito e de Ciências Econômicas da Universidade de Limoges, na França, tal projeto reúne nomes como Michel Prieur, Jean-Pierre Marguénaud, Gerárd Monédiaire, Julien Betáille, Bernard Drobenko, JeanJacques Gouguet, Jean-Marc Lavieille, Séverine Nadaud e Damien Roets.

Para contextualizar os deslocados ambientais, o Prof. Prieur informa que só em 2010 houve uma sucessão de catástrofes ecológicas, tais como terremotos no Haiti e no Chile, inundações no Pa-

determinado âmbito jurídico, levariam à inconstitucionalidade por omissão. É interessante notar, ainda em relação ao ambiente, que o chamado "mínimo ecológico essencial", por muitos proclamado, na opinião do Prof. Michel Prieur se mostra incompatível com a própria finalidade da proteção ambiental, cujo objetivo é atingir o seu nível mais elevado, e não, o mínimo. No cruzamento entre ambiente e direito internacional dos direitos humanos, sem dúvida cabe afirmar que a proibição de retrocesso existe em ambos os ordenamentos. Ver CONGRESSO INTERNACIONAL “O NOVO NO DIREITO AMBIENTAL POR MICHEL PRIEUR”. Auditório da Procuradoria Regional da República, em São Paulo, 01 set. 2010. 98 ACNUR. Mudança climática, desastres naturais e deslocamento humano: a perspectiva do ACNUR, 2009, p. 9.

99 ACNUR. Summary of Deliberations on Climate Change and Displacement, abr. 2011. Ver Terminiello, 2012, p. 164.

100 Ver, sobre a situação brasileira, GODOY GUALANO, Gabriel. El caso de los haitianos en Brasil y la vía de la protección humanitaria complementaria. In: ABRAMOVICH, Víctor et al. Protección Internacional de Refugiados en el Sur de Sudamerica. 1. ed. Lanús (Argentina): Ed. De la UNLa, 2012, p. 403-418. 
quistão e na China, e incêndio florestal na Rússia, o que causou o deslocamento das pessoas sobreviventes das áreas afetadas para outras regiões dentro ou fora do país. É preciso, inclusive, reconhecer o problema de divisão geográfica no mundo. Em 2008, 90\% dos deslocamentos aconteceram na Ásia e na África; com cerca de $10 \%$ da população mundial, coube ao continente africano $25 \%$ dos refugiados ambientais; e $80 \%$ das pessoas deslocadas são acolhidas em países em vias de desenvolvimento.

A necessidade de uma Convenção de Refugiados Ambientais decorre de fatos como a Convenção de Genebra sobre os refugiados políticos (1951) a qual não se adapta à questão dos deslocados ambientais, na medida em que apenas outorga o status de refugiado àquele que é perseguido. A Convenção de Genebra não se aplica aos riscos ambientais.

Não basta emenda à Convenção de Genebra para solucionar esse problema. Pois além dos deslocados externos, haveria o caso dos deslocados internos. Nesse Projeto de Convenção Internacional dos Refugiados Ambientais, é importante destacar que se protegem não apenas as pessoas físicas, mas também as famílias.
Entre os princípios e obrigações aqui trazidos, estão: obrigação de acolher (art. $1^{\circ}$ ), em nome do princípio da solidariedade e sem discriminação; princípio da responsabilidade comum, mas diferenciada; e princípio da proximidade (geográfica e cultural), a ser conciliado com a obrigação de acolher. Os deslocados temporários teriam direito ao alojamento, à reinstalação, ao retorno e à permanência prolongada. Por sua vez, as famílias e as populações teriam direitos específicos à preservação de sua unidade e às minorias.

Em suas conclusões, o Prof. Prieur considera o projeto de Convenção Internacional sobre Deslocados Ambientais uma abordagem global universal do problema, sendo a única forma de dispor de ferramentas e financiamentos para enfrentá-lo. Além disso, os deslocados ambientais não podem ter seus direitos humanos violados, impondo-se uma sinergia entre o direito ao meio ambiente, os direitos humanos e o direito humanitário. ${ }^{101}$

4. Por ocasião do V Seminário Nacional "Cátedra Sérgio Vieira de Mello", com foco em "Cartagena + 30. Perspectivas da Academia", ${ }^{102}$ coube a Liliana Lyra Jubilut ${ }^{103}$ a Relatoria da proposta de atualização da Declaração de Carta-

101 Ver CONGRESSO INTERNACIONAL “O NOVO NO DIREITO AMBIENTAL POR MICHEL PRIEUR”, no Auditório da Procuradoria Regional da República, em São Paulo, 01 det. 2010. In: Blog neicolaborador, 03 set. 2010.

102 Em 11 e 12 de setembro de 2014, ocasião do Encontro Nacional das Cátedras Sérgio Vieira de Mello, em Porto Alegre.

103 A Professora Doutora LILIANA LYRA JUBILUT é Mestra e Doutora em Direito pela USP; LLM em International Legal Studies, pela New York School of Law; 
gena de las Indias, Colômbia (1984). Na sessão plenária de 12 de setembro/14, colocada em debate e votação a chamada Declaração da Academia no Marco de Cartagena +30 , foram aprovados, entre outros, dois artigos diretamente relacionados com o tema deste trabalho.
Em 11 de outubro/2014, foi divulgado o texto final dessa Declaração, lançada oficialmente em evento na Universidade de Santos-SP (31 de outubro). Leia-se a parte relacionada, de modo especial, com o presente artigo:

Declaração da Academia no Marco de Cartagena +30

- Declaração sobre Proteção Integral a Refugiados e Outros Migrantes Forçados e para a Construção de um Efetivo Espaço Humanitário

Em 2014, no marco do trigésimo aniversário da Declaração de Cartagena sobre Refugiados, de 1984, a Academia busca uma vez mais contribuir para a proteção humana e humanitária na região. Tendo em vista que os problemas ambientais - naturais e/ou ocasionados pela atividade humana - geram fluxos de migrantes forçados, bem como considerando que as lacunas jurídicas a esse respeito, deixam essas pessoas em situação de desproteção uma vez que não contemplam-se os impactos que poderiam ter no próprio país de origem, país(es)de trânsito e na comunidade/país de acolhida.

\section{(...)}

Nesse sentido, e em face da intensificação e diversificação das dinâmicas migratórias que impactam a América Latina e o Caribe, incluindo a manutenção de antigos movimentos de deslocamento forçado e de migração por questões de desenvolvimento, o aumento da vulnerabilidade de grupos migratórios específicos, o fato de que as mudanças climáticas devem produzir mais processos de migração forçada, e o surgimento de novos grupos e fluxos migratórios, a Academia busca contribuir para a consolidação da região como efetivo espaço humanitário, adotando a presente Declaração. Recordando-se a prevalência da proteção à dignidade humana e aos direitos humanos como marcos de ação; Ressaltando-se a congruência das diversas vertentes de proteção da pessoa humana e das diversas dimensões dos direitos humanos; Destacando-se os avanços obtidos na América Latina e Caribe em termos de proteção à população refugiada e deslocada interna de modo coletivo ou pela legislação interna dos Estados;

Lembrando e elogiando a tradição do direito de asilo na região americana;

Resgatando o relevante papel da Academia na criação da Declaração de Cartagena sobre Refugiados de 1984; Considerando o fundamental papel da Academia na concepção, implementação, desenvolvimento e interpretação do Direito Internacional dos Refugiados em geral, da Declaração de Cartagena sobre Refugiados de 1984 em especial, e do Direito Internacional Humanitário e dos Direitos Humanos; bem como o papel central da Academia na análise das complexidades e da constante transformação da natureza e dos impactos regionais dos fluxos migratórios e das consequentes bases legais; Destacando-se a vontade e a necessidade de se estabelecer efetivamente um espaço humanitário ampliado de proteção

Advogada do Centro de Acolhida para Refugiados da Cáritas Arquidiocesana de São Paulo e Consultora do Projeto CASP/ACNUR de Facilitação da Criação do Conselho Brasileiro sobre Refugiados. 
na América Latina e no Caribe; Aceitando a existência de desafios impostos pelos novos fluxos migratórios e a imperativa necessidade de conjugação dos interesses estatais e das necessidades de proteção do ser humano para seu enfrentamento; Tendo em vista que os problemas ambientais - naturais e/ou ocasionados pela atividade humana - geram fluxos de migrantes forçados, bem como considerando que as lacunas jurídicas a esse respeito deixam essas pessoas em situação de desproteção, uma vez que não são contemplados os possíveis impactos no próprio país de origem, país(es)de trânsito e na comunidade/país de acolhida; Recordando-se que a baliza de legitimidade das ações estatais devem ser os direitos humanos para todas as pessoas, independentemente de seus status jurídico, de cidadania ou de nacionalidade; Tendo em vista que a população migrante na América Latina e no Caribe ainda enfrenta grandes desafios em termos de reconhecimento, recepção, proteção, integração e respeito a seus direitos nos Estados de acolhida; Destacando-se a contínua importância da Declaração de Cartagena sobre Refugiados e de seus processos revisionais, bem como o fato de que o presente documento da Academia não pretende substituir nenhum outro produzido no marco de Cartagena +30 , mas sim somar esforços para a proteção de migrantes forçados na América Latina e no Caribe; $\mathbf{E}$ considerando-se a premente necessidade de avanços normativos, políticos e de implementação de respeito aos seres humanos em situações de crise com efeitos migratórios, a Academia propõe as SEGUINTES RECOMENDAÇÕES como diretrizes e itinerários a serem adotados na definição, adoção, implementação, e interpretação das políticas migratórias pelos Estados Americanos:

(...)

13. Que os Estados da América Latina e do Caribe estabeleçam, de modo isolado ou coletivamente, formas de proteção aos deslocados ambientais, seja pela interpretação ampliada do conceito regional de refugiados, entendendo as questões ambientais como inseridas na temática dos direitos humanos e, portanto, englobadas nas situações de grave e generalizada violação de direitos humanos, seja pela criação de status migratório específico para os deslocados ambientais permanentes, seja pela criação de status migratório específico para os deslocados ambientais temporários, ou ainda pela combinação de uma ou mais dessas recomendações;

\section{(...)}

25. Que migrantes tenham respeitados todos os seus direitos, a partir dos padrões mínimos estabelecidos na Declaração Universal dos Direitos Humanos, na Declaração Americana dos Direitos e Deveres do Homem, na Convenção sobre o Estatuto de Refugiado, na Convenção Internacional sobre a Eliminação de todas as Formas de Discriminação Racial, nos Pactos Internacionais de Direitos Civis e Políticos e de Direitos Econômicos Sociais e Culturais, no Protocolo à Convenção sobre o Estatuto de Refugiado, na Convenção Americana dos Direitos Humanos, na Convenção Contra a tortura e outros Tratamentos ou penas Cruéis, Desumanas ou Degradantes, na Declaração sobre o Direito ao Desenvolvimento, na Declaração do Rio sobre Meio Ambiente e Desenvolvimento, na Declaração de Viena sobre Direitos Humanos, na Declaração Universal sobre Diversidade Cultural, na Convenção sobra a Proteção e a Promoção da Diversidade das Expressões Culturais, na Convenção Internacional sobre a Proteção dos Direitos de Todos os Trabalhadores Migrantes e dos Membros das suas Famílias, e na Declaração do Rio sobre Desenvolvimento Sustentável, e em todos os demais documentos que compõem o núcleo duro de proteção ao ser humano, ou que garantem proteção aos reflexos jurídicos da dignidade humana;

$$
\text { (...) }
$$

São Paulo, 31 de outubro de 2014 


\section{CONSIDERAÇÕES FINAIS}

A ONU e demais órgãos ou instrumentos internacionais visam, essencialmente, à paz. Nesse contexto, Direitos Humanos, Direito Humanitário, e de um de seus pontos nevrálgicos, o Direito dos Refugiados, ou mediante aproximações/convergências entre tais vertentes, o que denominaríamos abreviadamente de Direito Internacional dos Direitos Humanos, podemos ter uma visão sobre os desprotegidos, os que são vítimas de ações humanas ou desastreis naturais. A enumeração dos que são capazes ou forçados a migrar - apátridas, migrantes (imigrantes ou emigrantes), asilados, exilados, refugiados, desterrados, desenraizados, deslocados internos ou externos - por si só, demonstra a gravidade do fenômeno e as dificuldades no enfrentamento do problema. O objetivo deste trabalho consistiu em particularizar um dos aspectos mais angustiantes de nosso tempo, o desrespeito humano à mãe-terra $\mathrm{e}$ a consequência que está à vista de todos. As mudanças climáticas, as agressões à biodiversidade, $\mathrm{o}$ desprezo ao uso sustentável de energia e às próximas gerações, obrigam-nos a enumerar, mais uma vez, os atingidos por essa catástrofe. Tal enumeração é dispensável, por óbvio. O cruzamento entre refugiados, deslocados, e o direito ambiental, obriga o estudioso a debater temas os mais variados, e propostas sempre abertas à divergência, às emen- das e novos paradigmas. Termos como globalismo pluriversalistaI, ecologismo constitucional/convencional, e outros aí estão, para o desenvolvimento dos estudos acadêmicos. A lembrança de Sérgio Vieira de Mello é imprescindível.

Neste ano da graça de 2014, temos o marco do trigésimo aniversário da Declaração de Cartagena sobre Refugiados, que assinalamos com o V Seminário Nacional Cátedra Sérgio Vieira de Mello em nossa Universidade Federal. Coube a relatoria da Declaração da Academia no Marco de Cartagena + 30, à Professora Doutora Liliana Lyra Jubilut, e nos arts. 13 e 25 é possível a leitura relacionada com os dois temas que se cruzam, neste trabalho: deslocados/refugiados e mudanças climáticas. Destaque especial para a proposta de "interpretação ampliada do conceito regional de refugiados", e inserção das questões ambientais "na temática dos direitos humanos e, portanto, englobadas nas situações de grave e generalizada violação" de tais direitos. Entre outras possibilidades, lute-se pela "criação de status migratório específico para os deslocados ambientais permanentes", bem como para "status migratório específico" aos deslocados ambientais temporários. Por fim, combinem-se uma ou mais dessas recomendações.

Certamente, nem tudo são boas notícias. Tratamos aqui de temas que são capazes de tirar o sono dos estudiosos, dos jovens rebeldes em busca de causas 
nobres - e estendemos o pensamento para além de nossa época, preocupandonos com as gerações futuras.

Temos um compromisso com a história do direito e das relações internacionais, e nesta área memória e verdade devem ser invocadas, para que fatos deprimentes, não se repitam. Temos um compromisso com o futuro, pois também por ele somos responsáveis ou seremos responsabilizados. Vale dizer quer temos um direito-dever intergeracional, e expressões como globalismo pluriversalista e ecologismo constitucional/convencional alertam-nos para a necessidade de lidar em duas frentes: (a) do pragmatismo cotidiano, que aparece na atuação direta perante refugiados - sejam referência os jovens

\section{REFERÊNCIAS}

ABRAMOVICH, Víctor et.al. Protección Internacional de Refugiados en el Sur de Sudamerica. 1. ed. Lanús, Argentina: Ed. De la UNLa, 2012.

ACNUR. Forced Displacement in the Context of Climate Change: Challenges for Status Under International Law. Documento apresentado ao Grupo de Trabalho especial sobre a cooperação a longo prazo no Marco da Convenção das Nações Unidas sobre a Mudança Climática, 19 mai. 2009.

ACNUR. Memoria del Vigésimo Aniversario de la Declaración de Car- estudantes do GAIRE (Grupo de Assessoria a Imigrantes e Refugiados), grupo transdisciplinar, constituído por alunos dos cursos de Direito, Relações Internacionais, Ciências Sociais e Psicologia da Universidade Federal do Rio Grande do Sul -, e (b) do pensamento ativo presente nas Cátedras Sérgio Vieira de Mello, das universidades brasileiras.

O melhor exemplo dessa combinação entre ação e pensamento só poderia estar exatamente em Sérgio Vieira de Mello, mestre e doutor em filosofia, em Friburgo e na Sorbonne, e integrante de missões de campo, do ACNUR, em Bangladesh, no Sudão, em Chipre, no Camboja, em Moçambique, no Líbano, na Bósnia, em Ruanda, no Timor Leste e, finalmente, no Iraque. tagena sobre los Refugiados. San José: Editorama, 2005.

ACNUR. Mudança climática, desastres naturais e deslocamento humano: a perspectiva do ACNUR. 2009.

ARAÚJO, Nadia de; ALMEIDA, Guilherme Assis de (Coord.). O direito internacional dos refugiados: uma perspectiva brasileira. Rio de Janeiro, Renovar, 2001.

ÁVILA, Humberto. Teoria dos Principios. São Paulo: Ed. Malheiros, 2014.

AZEVEDO, Tupinambá Pinto de. Breves anotações sobre os Direitos dos 
Refugiados. In: (Org.). Direito Internacional Penal e a Proteção dos Direitos Humanos. Porto Alegre: Dom Quixote Ed., 2013, p. 15-70 . AUMAN, Zygmunt. Modernidade líquida. Rio de Janeiro: Jorge Zahar, 2001. Identidade. Rio de Janeiro: Jorge Zahar Editor, 2005, p. 16.

BECK, Ulrich. La sociedad del riesgo. Barcelona: Paidós, 2002, p. 28.

BERTONI, Liliana (Coord.). Las papeleras en cuestión: un recorrido por el derecho ambiental e internacional de La Haya al Mercosur. Buenos Aires: Eudeba, 2010.

BOBBIO, Norberto. A Era dos Direitos. Rio de Janeiro: Ed. Campus, 1992. BOSI, Ecléa (Org.). Simone Weil: A Condição Operária e Outros Estudos Sobre a Opressão. Rio de Janeiro: Paz e Terra, 1979.

BOUCHET SAULNIER, Françoise. Dictionaire pratique du Droit Humanitaire. Paris: Éditions La Découverte, 1998.

CANÇADO TRINDADE, Antônio Augusto. Tratado de Direito Internacional dos Direitos Humanos. v. I, 2. ed. Porto Alegre: Sérgio Antonio Fabris Ed., 2003.

. As três Vertentes da proteção Internacional da pessoa humana: Aproximações ou convergências entre os Direitos Humanos, o Direito Humanitário e o Direito dos Refugiados. In: - Tratado de

Direito Internacional dos Direitos Humanos. v. I, 2. ed. Porto Alegre: Sérgio Antônio Fabris, 1997.

CAPPELLETTI, Mauro. Proceso, ideologias, sociedad. Buenos Aires: Ed. Jurídicas Europa-America, 1974.

Cherpitel, D. Breaking the cycle. Our Planet, v. 11, n. 3; 2002. Disponível em: <http://www.ourplanet.com/ imgversn/113/cherp.html>.

CHIARELLO, Leonir Mario (Coord.). Las Políticas Públicas Sobre Migraciones y la Sociedad Civil en América Latina: Los casos de Argentina, Brasil, Colombia y México. Nova Iorque: Scalabrini International Migration Network, 2011.

COHEN, R.; BRADLEY, M. Disasters and Displacenent: Gaps in Protection. Journal of International Legal Studies, v. 1, 2010.

COMPARATO, Fábio Konder. A Afirmação Histórica dos Direitos Humanos. IV Ed. São Paulo: Ed. Saraiva, 2005, p. 90.

CORTE INTERAMERICANA DE DERECHOS HUMANOS. Condición Jurídica y Derechos de los Migrantes Indocumentados. Opinión Consultiva OC-18/03 del 17 de septiembre de 2003. Serie A No. 18. Disponível em: $<$ http://www.corteidh.or.cr/opiniones.cfm $>$. Acesso em: 12 nov. 2012.

DECLARAÇÃO DE CARTAGENA. Novembro 1984. Disponível em: $<$ http://www.acnur.org/t3/portugues/ 
recursos/documentos/>. Acesso em: 10 nov. 2012.

DECLARAÇÃO DE SAN JOSE SOBRE REFUGIADOS E PESSOAS DESLOCADAS. Colóquio Internacional em Comemoração do Décimo Aniversário da Declaração de Cartagena sobre Refugiados. S. José, 5-7 de Dezembro de 1994. Disponível em: < portal.mj.gov.br/services/.../FileDownload.EZTSvc.asp >. Acesso em: 10 nov. 2012.

IASC. Proteção das pessoas afetadas pelos desastres naturais. Diretrizes Operacionais do Comitê Permanente entre Organismos (IASC) sobre a proteção dos direitos humanos em situações de desastres naturais. Projeto de Brookings-Bern sobre Deslocamento Interno, jun. 2006.

GAUTIER, Arlete. O Destino das Mulheres. In: FERRO, Marc (Org.). $O$ Livro Negro do Colonialismo. RJ: EDIOURO, 2004, cap. IV, p. 660707.

GODOY GUALANO, Gabriel. El caso de los haitianos en Brasil y la vía de la protección humanitaria complementaria. In: ABRAMOVICH, Víctor et.al. Protección Internacional de Refugiados en el Sur de Sudamerica. 1. ed. Lanús, Argentina: Ed. de la UNLa, 2012, p. 403-418.

GOMES, Luiz Flavio; VIGO, Rodolfo Luis. Do Estado de Direito Constitucional e Transnacional: Riscos e
Precauções. SP: ed.Premier Máxima, 2008.

GOMES, Luiz Flávio; MAZZUOLI, Valerio de Oliveira. DIREITO SUPRACONSTITUCIONAL: Do absolutismo ao Estado Constitucional e Humanista de Direito. São Paulo: Revista dos Tribunais, 2010

HUESA VINAIJA, Rosario (Coord.). Derechos humanos, responsabilidad internacional y seguridad colectiva: Intersección de sistemas. Estudios en homenaje al profesor Eloy Ruiloba Santana. Madri: Marcial Pons, 2008.

INTERNAL DISPLACEMENT MONITORING CENTER (IDMC). Displacement due to natural hazard-induced disasters: Global estimates for 2009 and 2010. Junho de 2011, p. 4. Disponível em: $<\mathrm{http}: / / w w w$. internal-displacement.org>.

JUBILUT, Liliana Lyra. $O$ direito internacional dos refugiados e sua aplicação no ordenamento jurídico brasileiro. São Paulo: Ed. Método/ UNHCR-AcNUR, 2007.

KAUFMAN, Gustavo Ariel. Dignus inter pares: Un análisis comparado del derecho antidiscriminatorio. Buenos Aires: Abeledo Perrot, 2010.

KELSEN, Hans. Compulsory Adjudication of International Disputes. In American Journal of International Law, v. 37, n. 3, p. 399, 1943), 3, p. 399.

MARCOVITCH, Jacques. Vieira de Mello: pensamento e memória. São 
Paulo: Saraiva/EDUSP/ Fundação Bunge, 2004.

MARTÍNEZ ESCAMILLA, M. La inmigración como delito: Un análisis políticocriminal, dogmático y constitucional del tipo básico del art.318 bis CP 2007. Barcelona: Atelier, 2007.

MAZZUOLI, Valerio de Oliveira. O controle jurisdicional da convencionalidade das leis. São Paulo: RT, 2009.

MIRANDA, João Paulo Rocha de et.al. Painel Intergovernamental de Mudanças Climáticas (IPCC): O Direito Ambiental como Instrumento Mitigador das Queimadas na Amazônia Brasileira e das Mudanças Climáticas Decorrentes do Aumento das Emissões de Gases do Efeito Estufa. In BENJAMIN, Antonio Herman; LECEY, Eladio; CAPPELLI, Silvia. Mudanças Climáticas, Biodiversidade E Uso Sustentável De Energia. São Paulo: Imprensa Oficial, 2008, p. 830.

MORIKAWA, Márcia Mieko. Deslocados internos: entre a soberania do Estado e a protecção Internacional dos Direitos do Homem: uma crítica ao sistema internacional de protecção dos refugiados. Bol. Fac. Direito. STVDIA IVURIDICA 87. Coimbra: Coimbra Editora, 2006. MYERS, Norman. Environmental Refugees: An emergent security issue. Prague: XVIII Economic Forum. 23-27 mais 2005. Disponível em:
$<$ http://www.osce.org/ documents/ eea/2005/05/14488_en.pdf $>$ Acesso em: 30 mar. 2009.

NEVES, Marcelo. Transconsitucionalismo. São Paulo: Martins Fontes; 2009.

PEREIRA, Gustavo Oliveira de Lima. Apátridas e refugiados: direitos humanos a partir da ética da alteridade. Cadernos IHU, n. 181, ano 10. São Leopoldo, UNISINOS/RS, 2012. . A pátria dos sem pátria: direitos humanos \& alteridade. Porto Alegre: Ed. Ritter, 2011. Direitos Humanos e Hospitalidade: a proteção internacional para apátridas e refugiados. São Paulo: Atlas, 2014.

POWER, Samanta. O homem que queria salvar o mundo. São Paulo: Companhia das Letras, 2010.

PREGER, Claus Michael. Doktors: conto de memória. Médicos alemães, austríacos e húngaros no Rio Grande do Sul durante o século 20. Porto Alegre: Libretos, 2011.

PRIEUR, Michel et al. Projet de convention relative au statut international des déplacés environnementaux. Revue européenne de droit de l'environnement, $n$. 4, 2008. Disponível em: <http://www.cidce.org/pdf/ Projet $\% 20$ de $\% 20$ convention $\% 20$ relative $\% 20$ au $\% 20$ statut $\% 20$ international $\% 20$ des $\% 20$ déplacés $\% 20$ environnementaux.pdf $>$. Acesso em: 20 fev. 2010. 
RAIOL, Ivanilson Paulo Corrêa. Ultrapassando fronteiras: A proteção jurídica dos refugiados ambientais. Porto Alegre: Nuria Fabris, 2010.

Revue Européenne de Droit de l'Environnement. Limoges: CRIDEAU, 2003-3, n. especial consagrado à Convenção Europeia da Paisagem. SAID, Edward. Reflexiones sobre el exilio. Barcelona: Editorial Debate- Ed. Mondadori, 2005. . Fora do lugar: memórias. São Paulo: Companhia das Letras, 2004. SHILLING, Flávia. E o exílio? Boletim do IBCCrim, ano 22, n. 263, São Paulo, out. 2014, p. 16.

TEIXEIRA, Anderson Vichinkeski. Teoria pluriversalista do direito internacional. São Paulo: Martins Fontes, 2011.

TUCCI CARNEIRO, Maria Luiza. Cidadão do mundo: o Brasil diante do Holocausto e dos judeus refugiados do nazifascismo (1933-1948). São Paulo: Perspectiva/FAPESP, 2010. VIEGAS, Eduardo Coral. O desenvolvimento sustentável como sobreprincípio. In: BENJAMIN, Antonio Herman et al. (Coord.). Mudanças Climáticas, Biodiversidade e Uso Sustentável de Energia. São Paulo: Imprensa Oficial, 2008.

ZAFFARONI, Eugenio Raúl. La Pachamama y el Mundo. Buenos Aires: Ed. Colihue/Ed. Madres de Mayo, 2012. ZOLO, Danilo. Il signore dela pace. Roma: Carocci, 1998. 